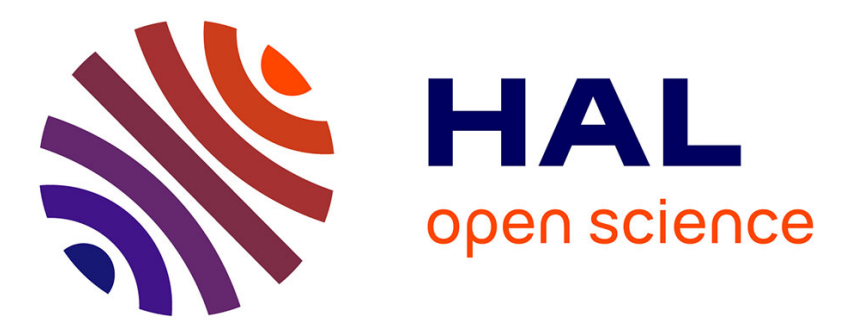

\title{
Expression of DNA ligase genes by ram spermatid nuclei and RNA in amphibian eggs
}

\author{
J.C. David, Maurice Loir, J. Lefresne, P. Thiebaud, J. Signoret
}

\section{To cite this version:}

J.C. David, Maurice Loir, J. Lefresne, P. Thiebaud, J. Signoret. Expression of DNA ligase genes by ram spermatid nuclei and RNA in amphibian eggs. Roux's archives of developmental biology: the official organ of the EDBO, 1986, 195, pp.186-192. 10.1007/BF02439437 . hal-02728622

\section{HAL Id: hal-02728622 \\ https://hal.inrae.fr/hal-02728622}

Submitted on 2 Jun 2020

HAL is a multi-disciplinary open access archive for the deposit and dissemination of scientific research documents, whether they are published or not. The documents may come from teaching and research institutions in France or abroad, or from public or private research centers.
L'archive ouverte pluridisciplinaire HAL, est destinée au dépôt et à la diffusion de documents scientifiques de niveau recherche, publiés ou non, émanant des établissements d'enseignement et de recherche français ou étrangers, des laboratoires publics ou privés.

\section{다(1)(2)}

Distributed under a Creative Commons Attribution - ShareAlikel 4.0 International 


\title{
Expression of DNA ligase genes by ram spermatid nuclei and RNA in amphibian eggs
}

\author{
J.C. David ${ }^{1}$, M. Loir ${ }^{2}$, J. Lefresne ${ }^{3}$, P. Thiebaud ${ }^{1}$, and J. Signoret ${ }^{3}$ \\ ${ }^{1}$ Laboratoire de Biochimie du Développement, L.A. N²56, C.N.R.S., Université de Remes I, Campus de Beaulieu, \\ 35042 Rennes Cedex, France \\ ${ }^{2}$ Laboratoire de Physiologie des Poissons, I.N.R.A., Université de Rennes I, Campus de Beaulieu, \\ 35042 Rennes Cedex, France \\ ${ }^{3}$ Laboratoire de Biologie du Développement, Université de Caen, 14000 Caen, France
}

\begin{abstract}
Summary. During animal development and gametogenesis two DNA ligases are found and successively expressed. In this study the two DNA ligases present in the axolotl egg and the two ligases present during ram sperm cell maturation were distinguished by biochemical and immunological methods. The expression of the genes for the heavy and light ram DNA ligases has been studied using transplantation of spermatid and sperm nuclei in axolotl eggs. We found that ram DNA ligases were expressed in axolotl egg cytoplasm. The exclusion phenomenon between the heavy and light form of DNA ligase is species-specific and involves a cytoplasmic mediator. In the transplanted ram germ cell nuclei the heavy ram DNA ligase expression was found to be sensitive to inhibitors of transcription while the light one was not. When mRNA was used, no exclusion process was observed and both the heavy and light enzyme expression were sensitive to cycloheximide and not to aamanitin. These results are discussed in terms of the possible stability of the gene-regulated state following nuclear transfer.
\end{abstract}

Key words: DNA ligase - Gene activity Nuclear transplantation -- Ram spermatids - Axolotl egg

\section{Introduction}

Two different molecular forms of DNA ligase have been reported in various species, including mammals (Söderhäll and Lindahl 1975, 1976), chicken (David and Vinson 1979), amphibian (David et al. 1979) and sea urchin (Lefresne et al. 1984). The shift from an enzymatic form to another unrelated one is described as a peculiar developmental event. In axolotl, a $6 \mathrm{~S}$ DNA ligase is present in the unfertilized egg and differentiated tissues, whereas an $8 \mathrm{~S}$ form is observed in developmental stages (Carré et al. 1981). The replacement of the slow migrating $(6 \mathrm{~S})$ by the fast migrating enzyme (8S) in early development has been proposed as a model for regulated changes in genetic activity (Signoret et al. 1981). Nuclear transplantation experiments have established that the specific enzymatic form of DNA ligase expressed by the injected nuclei is identical to the enzymatic form already present in the donor cell (Lefresne et al. 1983). This observation has been further supported by the use

Offprint requests to: I.C. David at the above address ol nucleocytoplasmic combinations of axolotl and Pleurodeles (Signoret et al. 1983). The isolation of messenger RNA (mRNA) for 8S DNA ligase and its cell-free translation have confirmed the involvement of specific structural genes in the process (Thiebaud et al. 1983).

In ram germ cells, a slow migrating form of DNA ligase (6.3S) is expressed in spermatocytes and in round spermatids. A faster migrating form ( $7.5 \mathrm{~S})$ is the only one expressed in elongated spermatids (David et al. 1982). The enzymatic shift occurs when spermatids elongate. Processes of spermiogenesis are unique among differentiating systems because diploid spermatocytes yield round haploid spermatids that become functionally anucleate while elongating due to chromatin condensation. In the present study, unfertilized eggs of axolotl were artificially activated and, in some experiments, ultra violet (UV) enucleated. Living nuclei of ram spermatids were prepared by cell lysis after spearation of germ cells by centrifugal elutriation (Loir and Lanneau 1982). A suspension of nuclei was injected in individual recipient axolotl eggs and ion later, the material was analysed on sucrose gradients and tested for DNA ligase activity. The light and heavy forms of DNA ligase from ram and urodele differ in their sedimentation mobilities, allowing the molecular forms of each species to be distinguished. Additional characterization has been performed with antisera directed against axolotl $6 \mathrm{~S}$ or axolotl 8S DNA ligase. Here we report that genes for DN $\Lambda$ ligases from ram germ cells can be expressed in axolotl eggs and that the regulated state of this gene is retained in transplanted nuclei. Moreover, the use of RNA extracted from either round spermatid or spermatozon resulted in the expression of stage-specific ram ligases when injected in axolot leggs.

\section{Materials and methods}

\section{Preparation of cells}

Axolotl eggs (Ambystoma mexicanum shaw). These were obtained and sorted as previously described (Signoret et al. 1981), artificially activated by an electrical stimulation, and eventually UV-enucleated. Eggs were maintained at $20^{\circ} \mathrm{C}$ in spring water unless otherwise specified, until frozen in liquid nitrogen.

Ram cells. Ram germinal cells were separated by centrifugal elutriation according to the method described by Loir and Lanneau (1982). Immediately after castration, a suspension 
of $1.2-1.9 \times 10^{9}$ testicular cells was prepared by Lrypsinization. After stopping the trypsinization by dilution with bovine serum albumin (BSA) at a final concentration of $0.5 \%$ and addition of an adcquate quantity of lima bean trypsin inhibitor, the suspension was loaded at $10 \mathrm{ml} / \mathrm{min}$ in a Bcckman elutriator driven by a $\mathrm{J} 21 \mathrm{~B}$ centrifuge at $4,000 \mathrm{rpm}$ and kept at $18^{\circ}-19^{\circ} \mathrm{C}$. By increasing the flow rate of the elutriation buffer $(0.5 \%$ BSA in $\mathrm{PBS}+3 \mathrm{mM}$ potassium Llactate) and dccrcasing the speed of the rotor, two germ cell populations $(S, D)$ were collected. Depending upon their degree of maturation, spermalids were classified into form types: steps 1-8 (Clermont and Leblond 1955), round spermalids; and steps 13-15, elongated spermatids. The populations $\mathrm{S}$ and $\mathrm{D}$ contained respectively, as a mean, $99 \%$ elongated spermatids and $95 \%$ round spermatids.

\section{Nuclear preparation and transplantation}

For population $\mathrm{D}$, the nuclei were prepared at $0-2^{\circ} \mathrm{C}$ with $0.033 \%$ Triton $X-100$ in solution $\mathrm{A}$ ('liris- $\mathrm{HCl} 1 \mathrm{mM}$, $\mathrm{pH} 6.8,0.25 \mathrm{M}$ sucrose, $2 \mathrm{mM} \mathrm{Mg} \mathrm{Cl}, 1.2 \% \mathrm{BS} \Lambda$ ). After homogenization in a Potter-Elvehjem pestle fitted with Teflon (5 15 strokes) the suspension was centrifuged at $700 \mathrm{~g}$ for $10 \mathrm{~min}$. The nuclear pellets were resuspended in solution A at a final concentration of 15-25 nuclei in $10 \mathrm{nl}$. For population $S$, the nuclei were prepared in the same way but with $0.080 \%$ Triton $X-100$ and the final nuclear concentration was adjusted to $45-60$ nuclei in $10 \mathrm{nl}$.

We injected $10 \mathrm{nl}$ of nuclei suspension into axolotl eggs following the procedure previously described (Signoret ct al. 1983). When $\alpha$-amanitin was used, unfertilized eggs were treated before activation for $24 \mathrm{~h}$ at $4^{\circ} \mathrm{C}$ with $200 \mu \mathrm{g}$ / $\mathrm{ml}$ of $\alpha$-amanitin in Steinberg fluid (Signoret et al. 1981). Simultaneously, the ram germ ccll nuclei were treated with $200 \mu \mathrm{g} / \mathrm{ml}$ of the inhibitor in Steinberg fluid/solution A (1 vol. 1 vol.) before being injected. The round germ cell nuclei were treated for $40 \mathrm{~min}$ at $2^{\circ} \mathrm{C}$, while the steps $13-15$ spermatid nuciei were treated for $1 \mathrm{~h} 20 \mathrm{~min}$ at $20^{\circ} \mathrm{C}$.

\section{Isolation of RNA and injection into eggs}

RNA was extracted from $25.10^{9}$ ram spermatozoa and $0.31 .10^{9}$ round spcrmatids separated by elutriation. The two samples were separately processed for RNA cxtraction according to a modification of the method described by Chirgwin et al. (1979). Spermatozoa and round spermatids were homogenized in $7 \mathrm{ml}$ of a solution containing $5 \mathrm{M}$ guanidine thiocyanate, $1 \mathrm{mM}$ EDTA, $2 \%$ sarcosyl and $0.1 \mathrm{M}$ sodium acetate $\mathrm{pH} 5.6$ at $20^{\circ} \mathrm{C}$. Homogenates were centrifuged for $20 \mathrm{~min}$ at $10,000 \mathrm{~g}$. Supernatants were layered on $1.2 \mathrm{ml}$ of $5.7 \mathrm{M}$ cesium chloride in $0.1 \mathrm{M}$ EDTA, $\mathrm{pH} 7.4$, and centrifuged for $20 \mathrm{~h}$ at $155,000 \mathrm{~g}$ in an $\mathrm{SW}_{50}$ rotor. The RNA pellet was dissolved in sterile ware at $4^{\circ} \mathrm{C}$ and precipitated three times in ethanol before bcing finally redissolved in sterile water. The RNA obtained $20 \mu \mathrm{g}$ and $210 \mathrm{Hg}$ respectively for spcrmatozoa and for round spermalids) was checked for integrity on agarose electrophoresis (Mc Master and Carmichael 1977).

The injection of RNA into eggs was performed with a glass micropipette, which delivered $10 \mathrm{nl}$ of fluid near the animal vegetative axis of the egg somewhat above the centre. No leakage was observed. Quantities of injected RNA per egg were 20 ng. Cycloheximide - treated eggs were activated in the presence of $10^{-3} \mathrm{M}$ of the drug before injection of RNA. The eggs were left in Stcinberg's solution for $9 \mathrm{~h}$ then frozen in liquid nitrogen and used within a week.

\section{Preparation of cellular extracts}

We homogenized $20-40$ eggs (approximately $0.1-0.5 \mathrm{~g}$ ) at $0^{\circ} \mathrm{C}$ in 3 vol. of extraction buffer $(0.5 \mathrm{M} \mathrm{KCl}, 20 \mathrm{mM}$ Tris, $2 \mathrm{mM}$ dithioerythritol and $0.2 \% \mathrm{NP} 40$ ), made $0.8 \mathrm{mM}$ in phenylmethylsulphonylfluoride (PMSF, Sigma) just belore use. The cellular extract was sonicated (Alcatel Sonicator) for three periods of $15 \mathrm{~s}$ with 10 -s intervals, at a dial setting of 2.2 , and centrifuged at $140,000 \mathrm{~g}$ for $60 \mathrm{~min}$ at $4^{\circ} \mathrm{C}$. The supernatant was used for sucrose gradient centrifugation.

\section{Sedimentation on sucrose gradients}

Aliquots of $250 \mu \mathrm{l}$ were layered on $5 \%-30 \%$ sucrose gradients in $0.5 \mathrm{M} \mathrm{CaCl}, 50 \mathrm{mM}$ Tris $\mathrm{HCl}, \mathrm{pH} 7.4,1 \mathrm{mM}$ EDTA, $2 \mathrm{mM}$ dithioerythritol and centrifuged for $15 \mathrm{~h}$ at $45,000 \mathrm{rpm}$ in an SW50-1 rotor at $4^{\circ} \mathrm{C}$. Fractions of $240 \mu \mathrm{l}$ were collected and assayed for enzyme activities.

\section{DNA ligase assay}

DNA ligase was assayed according to a modification of the method described by Olivera (1971). The substrate was prepared as follows: $1 \mathrm{mM}$ oligo $\mathrm{dT}_{12-18}$ (PL Biochemicals) in $50 \mathrm{mM}$ Tris, $\mathrm{pH} 7.6$, was incubated for $30 \mathrm{~min}$ at $37^{\circ} \mathrm{C}$ with 10 units $/ \mathrm{ml}$ of $E$. coli alkaline phosphatase. The reaction was stopped by the addition of $0.1 \mathrm{vol}$. of $20 \mathrm{mH}$ $\mathrm{KH}_{2} \mathrm{PO}_{4}$. This mixture was adjusted to $\mathrm{pH} 10.5$ with $1 \mathrm{~N}$ $\mathrm{NaOH}$ and kept for $15 \mathrm{~min}$ in a boiling water bath. After adjusting the $\mathrm{pH}$ to 7.6 with $1 \mathrm{~N} \mathrm{HCl}$, the extract was subjected to centrifugation at $10,000 \mathrm{rpm}$ for $10 \mathrm{~min}$. The supernatant, containing $200 \mu \mathrm{M}$ of dephosphorylated oligo $\mathrm{dT}_{12-18}$, was used for $5^{\prime}-{ }^{32} \mathrm{P}$ labelling in the presence of $60 \mathrm{mM}$ Tris $\mathrm{HCl}$, pH 7.6, $6 \mathrm{mM} \mathrm{MgCl}_{2}, 6 \mathrm{mM}$ 2-mercaptoethanol, $300 \mu \mathrm{M}$ ATP $(20 \mathrm{Ci}-\mathrm{mmol})$ and 15 units $/ \mathrm{ml}$ of T4infected $E$. coli $5^{\prime}$-polynucleotide kinase (Pl. Biochemicals) at $37^{\circ} \mathrm{C}$ until the plateau of incorporation was reached. The resulting $\left(5^{\prime}-{ }^{32} \mathrm{P}\right)$ oligo $\mathrm{dT}_{12-18}$ was stored at $-20^{\circ} \mathrm{C}$ unlil use.

The intensity and position of DNA ligase peaks on sucrose gradients were checked by the method of Modrich and Lehman (1970). For the determination of ligase activity, each assay $(0.3 \mathrm{ml})$ contained $6 \mu \mathrm{M}\left({ }^{32} \mathrm{P}\right.$ oligo d $\mathrm{T}_{12-18}$, $6 \mathrm{mM}$ poly (dA) (PL Biochemicals), $25 \mathrm{mM}$ Tris $1 \mathrm{ICl}$, $\mathrm{pH} 7.6,6 \mathrm{mM} \mathrm{MgCl}, 1 \mathrm{mM}$ ATP, $2.5 \mathrm{mM}$ dithiothreitol, $31 \mu \mathrm{g} / \mathrm{ml}$ BSA and $100 \mu 1$ enzyme solution. The samples were incubated at $37^{\circ} \mathrm{C}$ for $30 \mathrm{~min}$. After the addition of 1 unit of alkaline phosphatase and dilution with $300 \mu \mathrm{l}$ of ice-cold water they were incubated for $30 \mathrm{~min}$ at $80^{\circ} \mathrm{C}$. The samples were precipitated with TCA, $5 \%$ final concentration, filtered through Millipore filters and counted. One unit of DNA ligase is delined as the activity which renders $1 \mathrm{nmol}$ of $\left(5^{\prime}-{ }^{32} \mathrm{P}\right)$ oligo dT resistant to alkaline phosphatase in 30 min under standard conditions.

\section{Immunological methods}

The details for preparation and purification of antiscrum will be published elsewhere (Raimbaud et al., in prepara- 
tion). The $\mathrm{IgCr}$ fraction was purified by gel filtration on a sephadex G200 column. Non-immune IgG was similarly purified from the preimmunized serum. IgG-containing fractions were stored in $0.1 \mathrm{M}$ Tris $\mathrm{HCl}, \mathrm{pH} 8.0$ at $-80^{\circ} \mathrm{C}$.

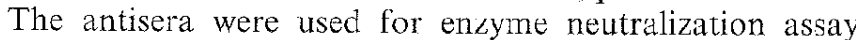
after serial dilutions of the antibodics in $50 \mathrm{mM}$ sodium phosphate, pII 7.6. The incubation of the enzyme fractions and serum protein was for $16 \mathrm{~h}$ at $4^{\circ} \mathrm{C}$ and the un-neutralized enzyme activity was assayed

\section{Results}

Genes for ram DNA ligases are expressed in amphibian cytoplusm

The DNA ligase activities in axolotl eggs were distinguishable by sucrose gradient centrifugation. Fxtracts from activated non-enucleated and enucleated eggs showed a sedimentation coefficient of $8 \mathrm{~S}$ and $6 \mathrm{~S}$ respectively (Fig. 1 $\Lambda$ ). The DNA ligase activitics present in ram spermatids were also distinguishable with respective sedimentation coefficients of $6.3 \mathrm{~S}$ and $7.5 \mathrm{~S}$ (Fig. $1 \mathrm{~B}$ ).

Ten hours after injection of ram spermatid nuclei in axolotl eggs, the extracls were analysed for their DNA ligase activities. Recipient eggs wcre used either with or without enucleation. Eggs injected with ram spermatid nuclei present a peak of ligase activity typical of the rccipicnt egg. Non-enuclcated eggs activated and injected with nuclei from either round or elongated spermatids expressed the axolotl $8 \mathrm{~S}$ ligase and either the $6.3 \mathrm{~S}$ (Fig. $1 \mathrm{C}$ ) or the $7.5 \mathrm{~S}$ (Fig. 1D) ram ligase. Enucleated eggs, similarly injected expressed the axolotl $6 \mathrm{~S}$ ligase and either the 6.3S (Fig. 1 E) or the 7.5S (Fig. $1 \mathrm{~F}$ ) ram ligase. If activated non-enucleated axolotl eggs were injected with a mixture of nuclei from round and elongated spermatids, the $8 \mathrm{~S}$ axolotly ligase was expressed together with both ram DNA ligases (Fig, 1G).

The identilication of the axolotl and ram ligases was further checked using antisera against the $6 \mathrm{~S}$ and the $8 \mathrm{~S}$ enzymes from inactivated and activated eggs respectively (Raimbaud et al., in preparation). After purification of the antisera (see Methods) enzyme inhibition assays were performed using the anli-8S antiserum against the $6 \mathrm{~S}$ axolotl and the $6.3 \mathrm{~S}$ and $7.5 \mathrm{~S}$ ram (Fig. $2 \mathrm{~A}$ ) enzymes and the anti $6 \mathrm{~S}$ antiserum against the $8 \mathrm{~S}$ axolotl, the $7.5 \mathrm{~S}$ and $6.3 \mathrm{~S}$ (Fig. 2B) ram enzymes. No cross-reactivity was observed. When the anti-8S antiserum was tested against the DNA ligase activities present in activated axolotl eggs injected with ram round spermatid nuclei, only one $(6.3 \mathrm{~S})$ peak of activity was observed, thereby indicaling the ram light DNA ligase (Fig. 2C). Repeating this experiment with activated axolotl eggs injected with nuclei from elongated spermatids, the $7.5 \mathrm{~S}$ peak was positively identified as the ram heavy enzyme (Fig. 2D)

When enucleated axolotl eggs were implanted with nuclei from round and elongated spermatids and the extracts incubated with anti-6S antiserum, the 6.3S (Fig. 2E) and 7.5S (Fig. 2F) activities were found. Extracts from activated axolotl eggs injected with a mixture of round and elongated spcrmatids and treated with anti-8S antiserum present the $6.3 \mathrm{~S}$ and $7.5 \mathrm{~S}$ peak activities (Fig. $2 \mathrm{G}$ ). These observations further establish the authenticity of axolotl and ram DNA ligase, and add to the evidence for expression of specific DNA ligase genes by forcign nuclei implanted in egg cytoplasm.

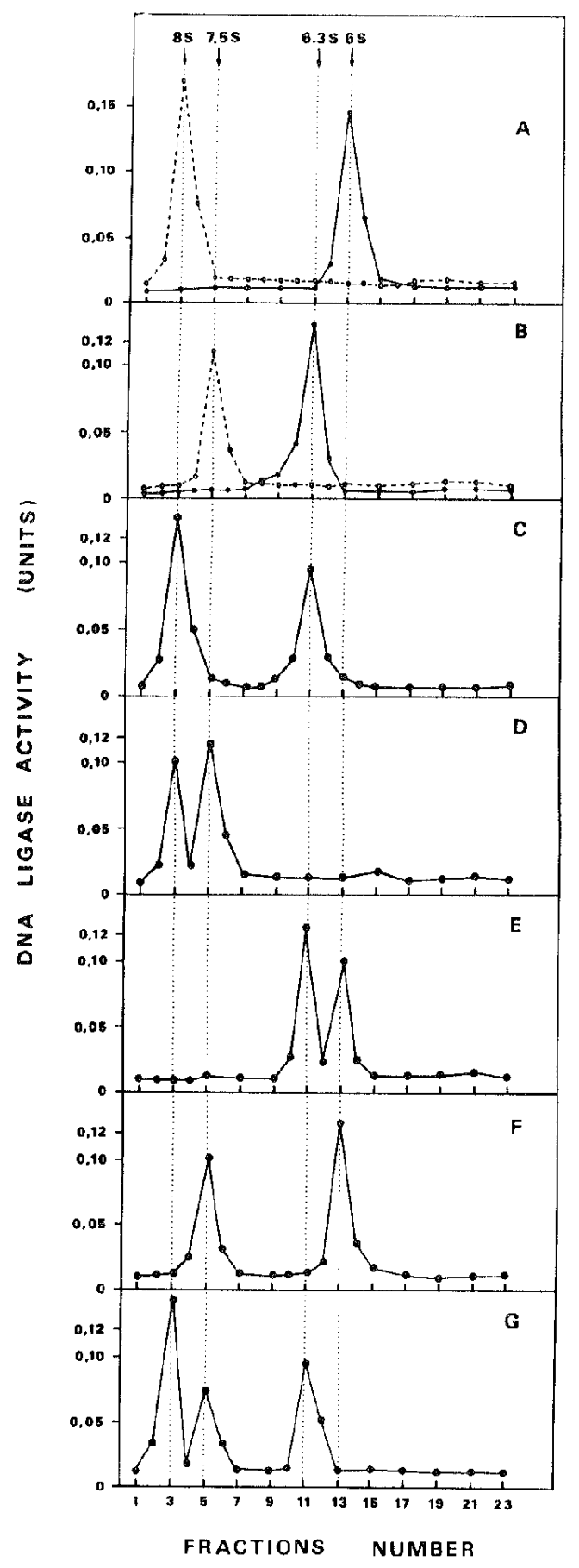

Fig. 1A-G. Sucrose gradient analysis of DN $\Lambda$ ligase activity in extracts of axolotl eggs and ram spermatids. $\boldsymbol{\Lambda}$ Extracts from activated enucleated axolotl eggs $(\leftrightarrow)$ and from activated non-enucleated axolotl egg (--). B Extracts from round spermatids ( $(>)$ ) and from elongated spermatids (--). C Extracts from activated axolot] cggs injected with nuclei from round spermatids. D Extracts from activated axolotl eggs injected with nuclei from elongated spermatids. E Extracts from activated enucleated axolotl eggs injected with nuclei from round spermatids. F Extracts from activated enuclcatcd axolotl eggs injected with nuclei from elongated spermatids. $\mathbf{G}$ Extracts from activated axolotl eggs injected with a mixture of nuclei from round and elongated spermatids. A series of internal reference markers has been used including beef liver catalase (11.2S), chick DNA polymerase alpha $(7.5 S)$, E. coli alkaline phosphatase $(6.3 \mathrm{~S})$, hen haemoglobin $(4.2 \mathrm{~S})$ and horse heart cy tochrome c $(2.1 \mathrm{~S})$ 


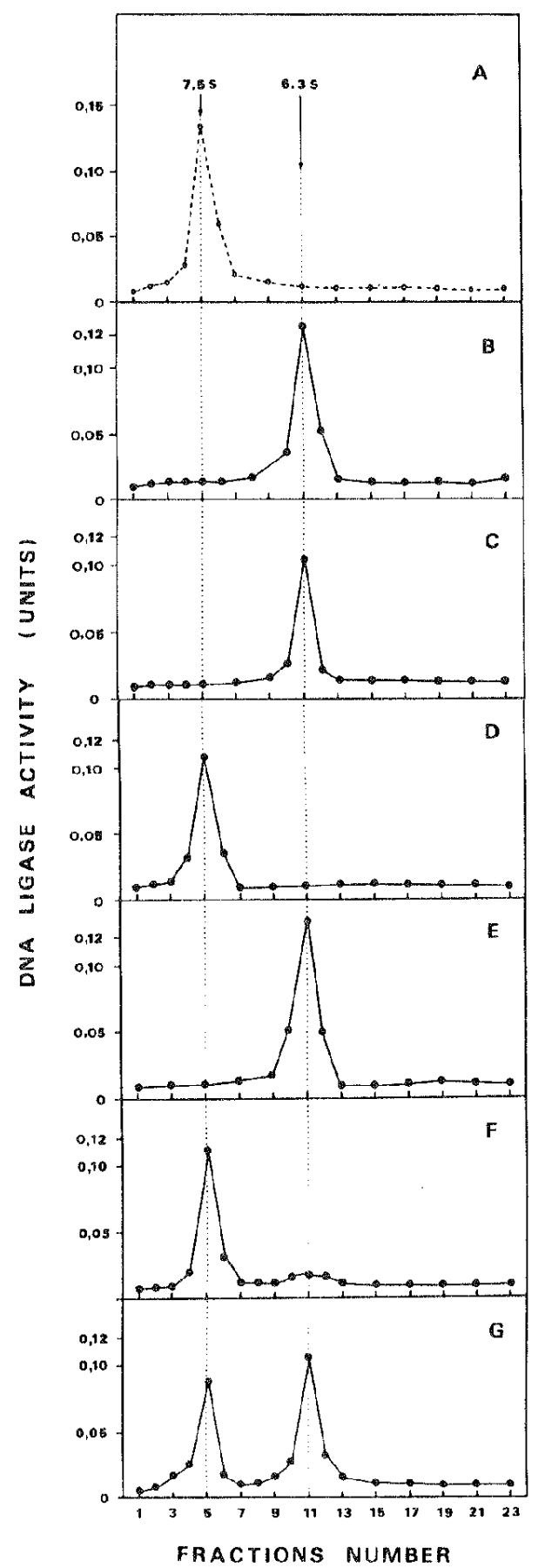

Fig. 2A-G. DNA ligase neutralization assay by specific antisera against the $8 \mathrm{~S}$ and $6 \mathrm{~S}$ axolotl enzyme. Before assaying the unneutralized enzyme activity, $10 \mu \mathrm{l}$ of the anti-axolotl $8 \mathrm{~S}$ antiscrum was preincubated at a 5-fold dilution with $100 \mu 1$ of cach of the sucrose gradient fractions 3-7 of the cxtracts from elongated spermatids $\mathbf{A} ; 10 \mu 1$ of the anti-axolotl $6 \mathrm{~S}$ antiscrum was preincubated at a 5 -fold dilution with $100 \mu \mathrm{l}$ of each of the sucrose gradient fractions $2-13$ of the extracts from round spermatids $\mathbf{B}$. Under the same conditions anti-axolot $8 \mathrm{~S}$ antiserum was used on fractions 3-7 from extracts of activated axolotl eggs injected with either nuclei from round spermatids $\mathrm{C}$ or nuclei from elongated spermatids D. Anti-axolotl $6 \mathrm{~S}$ antiserum was used on fractions $12-15$ from extracts of enucleated activated axolotl eggs injected with either nuclei from round $\mathrm{E}$ or elongated $\mathbf{F}$ spermatids. Anti-axololl DNA ligase $8 \mathrm{~S}$ was used on fractions 1-15 from extracts of activated axolotl eggs injected with a mixiure of nuclei from round and elongated spermatids $G$

\section{Exclusion process is species-specific}

An interesting phenomenon already mentioned in amphibians (Signoret et al. 1983) is the reciprocal control of the two expressions of $D N^{\top} \Lambda$ ligase. The light axolotl enzyme is stable in enucleated eggs, but disappears within a fcw hours when the heavy enzyme is produced. Moreover, genes for the heavy and light forms of DNA ligase have never been found expressed simultaneously in the same species. However, the present experiment shows that the light form of DNA ligase from axolotl enuclcatcd cytoplasm was not. diminished in the presence of the heavy form of ram ligase controlled by clongated spermatid nuclei (Fig. 1F). Nevertheless, this 6S axolotl ligase vanished when the $8 \mathrm{~S}$ type was expressed under the control of the female pronucleus in non-enucleated eggs, independently of the cxpression of the heavy type of ram ligase (Fig. 1D).

Similarly, the heavy axolotl ligase expressed in non-enucleated eggs did not interfere with the expression of the light ligase of ram produced after injection of ram round spermatid nuclei (Fig. 1C, 1D). When nuclei of round and elongated spermatids were mixed and injected simultancously into axolotl eggs, the two forms of ram ligase were observed in addition to the axolotl enzyme (Fig. 1G). Thus the two molecular forms of DNA ligase of one species may be expressed simultancously and co-exist, but only in a foreign cytoplasmic environment. "The "exclusion process" fails to operate between nuclei of different species or between homospecific nuclei in heterospecific cytoplasm. Nevertheless, the process does work between the two non-allelic genes of the same nucleus.

\section{Effects of inhihitors of transcription}

The shift from a $6 \mathrm{~S}$ to an 8S DNA ligase during axolotl development is sensitive to inhibitors of gene transcription (actinomycin D, amanitin Signorct et al. 1981). Eggs were injected with ram spermated nuclei following treatment of both the nuclei and the eggs with amanitin. In all experiments, the expression of the $8 \mathrm{~S}$ axolotl ligase was totally absent, while the 6S ligase was maintained undiminished. The two enzymes of axolotl and ram were present (Fig. 3A, dotted line) in the extracts of control activated axolotl eggs injected with round spermatid nuclei. When $\alpha$-amanitin was used, the $6.3 \mathrm{~S}$ ram ligase was expressed as in the absence of the inhibitor (Fig. 3 A, solid line).

When the injected nuclei werc from elongated spermatids, the enzyme activities observed in controls were heavy forms of axolotl and ram type (Fig. 3B, dotted line). However, when $\alpha$-amanitin was used, the heavy form (7.5S) of ram ligase was absent (Fig. $3 \mathrm{~B}$, solid line). In this case, a light ligase (6.3S) was cxpressed and this enzyme activity was resistant to antiserum directed against $6 \mathrm{~S}$ ligase from axolotl. This peak of activity was obviously assumed to be a light ligase of ram type. Thus the expression of the light form of enzyme by implanted nuclei appeared to be insensitive to inhibitors of transcription if already present in the donor cell. Moreover, this light DNA ligase is expressed as a consequence of such an inhibition for donor cells possessing the heavy form of enzyme and devoid of the light one.

\section{Translation of injected ram $R N A$ in axolotl eggs}

As depicted in Fig. 4, the injection of RNA extracted from ram round spermatids in activated axolot eggs resulted 


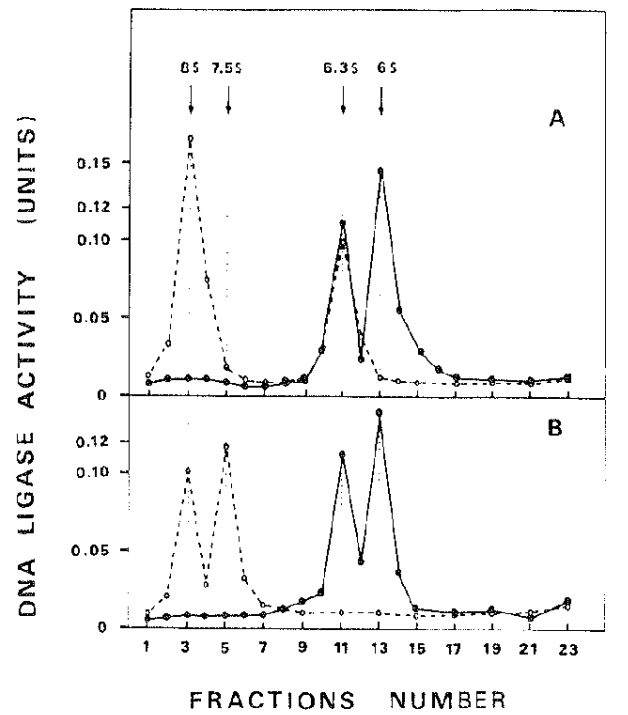

Fig. 3 A, B. Sucrose gradient analysis of DNA ligasc activity in exlracts of axolotl eggs injected with nuclei from cither round $A$ or elongated B spermatids in the absence (---) or presence of $\alpha$ amanitin $(-)$

in the expression of a $6.3 \mathrm{~S}$ enzyme together with the $8 \mathrm{~S}$ enzyme normally present in activated axolotl eggs (Fig. 4A). The injection of RNA cxtracted from spermatozoa resulted in the expression of a $7.5 \mathrm{~S}$ and the nomally observed $8 \mathrm{~S}$ enzyme (Fig. 4B). The injection of a mixture of equal amounts of RNA from round spermatids and spermatozoa resulted in the expression of three types of enzyme with sedimentation coefficients of 6.3,7.5 and 8S (Fig. 4C). Pretreatment with cycloheximide abolished the expression of the 6.3S and 8S enzymes (Fig, 4D) in activated axolotl eggs injected with RNA from round spermatids. A control with antisera against axolotl $6 \mathrm{~S}$ or $8 \mathrm{~S}$ positively identified the enzymes from different origins. The expression of $6.3 \mathrm{~S}$ and 7.5S DNA ligases in RNA-injected axolotl eggs was insensitive to a-amanitin (results not shown).

\section{Discussion}

The oocyte of Amphibia has been extensively used as a test system for expression of isolated DNA, RNA or whole nuclei (Gurdon and Mclton 1981). Mature eggs have proved to be a convenient system for studying the expression of genes controlling the molecular forms of DNA ligases (Lefresne et al. 1983). Using UV-enucleation cytoplasm can be preprepared with either one of the two enzymatic forms. On the other hand, transplanted nuclei can be from donor cells possessing either form of DNA ligise as a function of cell differentiation. The results reported in the present study are consistent with the stability of the regulated state of the genes for DNA ligase following nuclear transfer to egg cytoplasm. This assumption agrees with conclusions based upon intraspecific nuclear transplantations carried out using developmental stages of Amphibia (Signoret et al. 1984).

The expression of a gene by at nucleus transferred to a foreign cytoplasm raises the problem of the mechanism responsible for this expression. The possibility of a simple transfer of the terminal product can be ruled out because the intensity of the pcak in the recipient egg corresponds

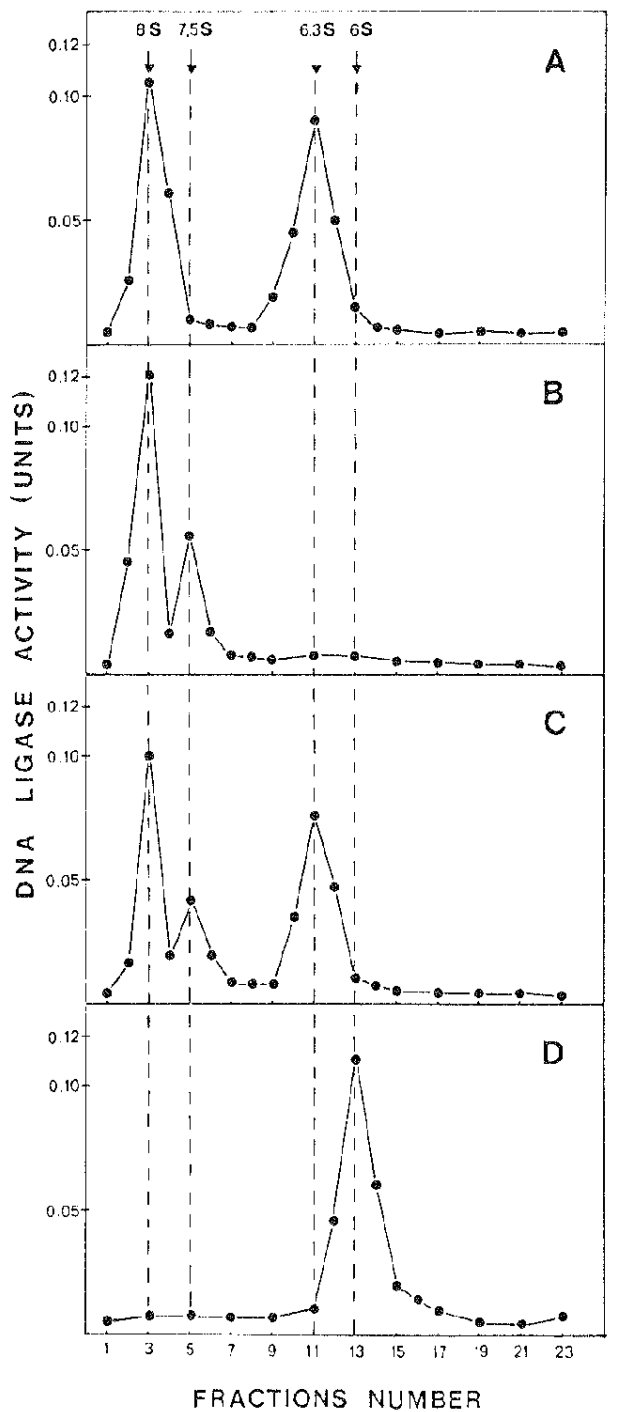

Fig. 4A-D. Sucrose gradient analysis of DNA ligase activity of activated axololl eggs injected with RNA extrated from ram round spermatids $\mathbf{A}$, ram spermatozoa $\mathbf{B}$ and a mixture of both $\mathbf{C}$. D Ligase activity in activated axolotl eggs pretreated with cycloheximide and injected with RNA from round spermatids

to a much greater amount of material than the injected amount of substance, i.e. about 3 orders of magnitude.

Another possibility is the translation of transcripts carried over with the injected material into the recipient egg. Such a post-transcriptional expression is expected to be resistant to $\alpha$-amanitin, and it could effectively support at least in part the expression of the light form of DNA ligase by ram round spermatid nuclei. Such nuclei have been shown to contain a significant amount of RNA (Toir 1972). Thus we consider that the nuclei from round spermatids are loaded with stable transcripts of the gene for the light form of DN $\Lambda$ ligase. These transcripts could result from previous transcription and it is not know if they are renewed by continuing transcription (Loir 1972; D'A gostino et al. 1978; Erickson et al. 1980; Fujimoto and Erickson 1982). Corresponding messengers allow translation into the terminal product in spermatocytes and spermatids (light form of DNA ligase), as well as in transferred nuclei where there is an eventual inhibition of transcription. 
The sensitivity of expression of the ram heavy form of DNA ligase to $\alpha$-amanitin will not allow this mechanism in the case of elongated spermatid nuclei. These transferred nuclei are assumed to carry on a complete expression of the gene, through transcription, processing and translation. With respect to elongated spermatids in situ, although no precise data allow us to definitely exclude the possibility that the expression of the heavy DNA ligase form carried on in the clongated spermatids is an exceptionally late direct genetic activity, many results strongly support the complete absence of transcription due to tight packaging of the chromatin (Monesi 1964; Moore 1971; Loir 1972; Kierszenbaum and Tres 1975; Geremia et al. 1978; Loir and Courtens 1980; Balhorn 1982). In such a case, the heavy DNA ligase would be synthesized at this stage under a post-transcriptional positive control on transcripts and/or mRNAs previously produced. This has alrcady been shown for another protein which appears in elongated spermatids simultaneously with the heavy DNA ligase, the protamine (Kleene et al. 1984), Such transcripts or mRNAs should be exclusively cytoplasmic and not introduced into the egg along with the nucleus. In clongated spermatid nuclei, transcripts for the light form of DNA ligase are still present although no longer expressed, probably as a consequence of the expression of the heavy form operating a post-transcriptional negative control. Stable RNAs may be inactivated in haploïd cclls by means other than degradation (Gold and Hecht 1981; Gold et al. 1983; Kleene et al. 1983, 1984; Stern et al. 1983). On the other hand, when in axolotl eggs, RNA from spermatozoa induced the synthesis of the heavy ligase form. Because the chromatin of elongated spermatids is very tightly packaged, we propose that the nuclei of these cells do not contain transcripts for the heavy ligase form but rather that $\mathrm{mRNA}$ coding for this protein is present in the cytoplasm. This form should result from the unmasking and processing of previously untranslatable transcripts in the intermediate spermatids, these cells being characterized by a massive transfer of the RNA from the nuclei to the cytoplasm. When elongated spermatid nuclei treated with $\alpha$-amanitin are implanted in egg cytoplasm, these long-lived transcripts yield messengers able to support the expression of the light form of enzyme. Induction of enzyme production by transcription inhibitores has becn reported in different systems (Tomkins et al. 1969, 1972). The process is suggested to involve long-lived transeripts and short-lived inhibitors of post-transcriptional expression.

The exclusion process controlling interaction bctween the two non-allelic genes has already been discussed (Signoret et al. 1983). The present report confirms the speciesspecilicity of the mechanism: it fails to work between ram and axolotl, just as it fails between axolotl and Pleurodeles. Moreover, the exclusion process does not opcrate intraspecifically when different nuclei, controlling both enzymes, are in a foreign cytoplasmic cnvironment. This result, already established with amphibian nuclei, is interpreted as indicating a species-specific cytoplasmic mediator in the process. However, as the process operates within the same nucleus even in a foreign cytoplasm, and as the light form seems to become uncxpressed some time before the heavy form becomes present (David et al. 1982), we suggest that a multi-level system of reciprocal controls is responsible for the exclusion process.

At the present time, it is unknown what modifications are induced by the cytoplasm of an amphibian egg in ram germ cell nuclei. Elongated spermatid nuclei posses a tightly condensed chromatin resistant to decondensation in the absence of a reduction of the -SS- bonds between protamine molecules (Loir and Lanneau 1978). Our results suggest that the gene for the heavy DNA ligase which is expressed in situ in elongated spermatids is in a non-repressed state. It would be interesting to know if some other genes, such as the protamine gene, which are also expressed in these cclls arc also expressed after transfer into axololl eggs.

Acknowledgemenls. This work was supported by a Grant Ministèro de l'Industrie et de la Recherche no. 82.E.1149 Programmo ct Erreurs du Développement Lmbryonnaire. The authors are grateful to Mrs. M. Mathelier and Mrs. de F. de Sallicr Dupin for assistance in manuscript preparation.

\section{References}

Balhorn R (1982) A model for the structure of chromatin in Mammalian sperm. J Cell Biol 93:298-305

Carré D, Signoret J, Lefresne J, David JC (1981) Enzymes involved in DNA replication in the Axolotl. I. Analysis of the forms and activities of DNA polymerases and DNA ligases during development. Dev Biol 87:114-125

Chirgwin JM, Przybyla AĹ, Mc Donald R, Rutter WJ (1979) Isolation of biologically active ribonucleic acid from sources enriched in ribonuclease. Biochemistry, 18:5294 5299

Clermont Y, Leblond $\mathrm{CP}$ (1955) Spcrmiogenesis of man, monkey, ram and other mammals as shown by the "periodic acid Schiff" technique. Am J Anat 96:229 253

D'Agostino A, Geremia R, Monesi V (1978) Post-meïotic gene activity in spermatogenesis of the mouse. Cell Differ 7:175-183

David JC, Vinson D (1979) Duality and developmental changes of thymic DNA ligases. Exp Cell Res $8: 358-364$

David JC, Vinson D. Lefresne J, Signoret J (1979) Evidence for a DNA ligase change related to early cleavage in Axolotl egg. Cell Differ 8:451-459

David JC, Vinson D, Loir M (1982) Developmental changes of DNA ligases during ram spermatogenesis. Exp Cell Res $141: 357-364$

Erickson RP, Kramer JM, Rittenhouse J, Salkeld A. (1980) Quantitation of $\mathrm{mRN}$ As during mouse spermatogenesis: protaminelike histone and phosphoglycerate kinasc-2 mRNAs increase after meiosis. Proc Natl Acad Sci (USA) 77:6086-6090

Fujimoto H, Erickson RP (1982) Functional assays for mRNA detect many new messages after male meiosis in mice. Biochem Biophys Res Com 108:1369-1375

Geremia R, D'Agostino A, Monesi V (1978) Biochemical evidence of haploid gene activity in spermatogenesis of the mouse. Exptl Cell Res $111: 23-30$

Gold B, Ilecht NR (1981) Differential compartimentalization of messcnger ribonucleic acid in murine testis. Biochemistry $30: 4871-4877$

Gold B, Stcrn L, Bradley FM, Hecht NB (1983) Gene expression during mammalian spermatogenis. II. Evidence for stage-specific differences in mRNA populations. J Exp Zool 225:123-134

Gurdon JB, Melton DA (1981) Gene transfer in Amphibian eggs and oocytes. Ann Rev Genct 15:189-218

Kierszenbaum AL, Tres LL (1975) Structural and transcriptional features of the mouse spermatid genome. I Cell Biol 65:258-270

Kleene KC, Distel RJ, Hecht NB (1983) cDNA clones encoding cytoplasmic polyA + RNAs which first appear at detectable levels in haploid phases of spermatogenesis in the mouse. Dev Biol 98:455-464

Kleene KC, Distel RC, Hecht NB (1984) Translational regulation and deadenylation of protamine mRNA during spermatogene-sis in mouse. Dev Bial 105:71-79

Lefresne J, David JC, Signoret J (1983) DNA ligase in Axolot1 
egg: a model for study of gene activity control. Dev Biol $96: 324-330$

Lefresne J, David JC, Signorct J (1984) Evidence for a DNA-ligase change related to early devclopment in sea urchin. J. Embryol Exp Morphol 82:51

Loir M (1972) Métabolisme de l'acide ribonucléique et des protéines dans les spermatocytes et les spermatides de Bélier. I. Incorporation et devenir de l'H-uridine. Ann Biol Anim Bioch Biophys 12:203 219

Loir M, Courtens JL (1980) Nuclear reorganization in ram spermatids. J Ultrast Res 67:309-324

Loir M, Lanneau M (1978) Transformation of ram spcrmatid chromatin. Exp Cell Res 115:231 243

Loir M, Lanneau M (1982) A strategy for an improved scparation of Mammalian spermatids. Gamete Res 6:179 188

Mc Master GK, Carmichael GG (1977) Analysis of single and double stranded nucleic acids on polyacrilamide and agarose gels by using glyoxal and acridine orange. Proc Natl Acad Sci $74: 3626-3634$

Modrich P, Lehman JR (1970) Enzymatic joining polynucleotids. J Biol Chem 245:3626-3634

Monesi V (1964) Ribonucleic acid synthesis during mitosis and meiosis in the mouse testis. J Cell Biol 22:521-532

Moorc GPM (1971) DNA-dependant RNA synthesis in fixed cells during spermatogenesis in mouse. Exp Cell Res 68:462-465

Olivera BM (1971) The DNA joining enzyme from Escherichia coli. In: Grossman $\mathrm{I}$, Moldave $\mathrm{K}$ (eds) Methods in enzymology, vol 21. Academic Press, New York, pp 319-322

Signoret J, Lefresne J, Vinson D, David IC (1981) Enzymes involved in DNA replication in Axolot1. II. Control of ligase activity during very carly development. Dev Biol 87:126-132

Signoret J, David JC, Lefresne J, Houillon C (1983) Control of
DNA ligase molecular forms in nucleocytoplasmic combinations of Axolotl and Pleurodeles. Proc Natl Acad Sci (USA) $80: 3368-3371$

Signoret J, Lefresne J, David IC (1984) Nuclear differentiation revisited: stabilized expression of the genes coding for DNAligetse in transfered nuclei. Differentiation 26:235-240

Söderhäll S, Lindahl T (1975) Two DNA ligases activities from calf thymus. Biochem Biophys Res Comm 53:910-916

Söderhäll S, Lindahl T (1975) Mammalian DNA ligases, scrological evidence for two separate enzymes. J Biol $\mathrm{Chcm}$ $250: 8438-8444$

Söderhäll S, Lindahl T (1976) DNA ligases of eucaryotes. FEBS Letters 67:1-8

Stern L, Kleene KC, Gold B, Hecht NB (1983) Gene expression during mammalian spermatogenesis. III. Changes in populations of mRNA during spermiogenesis. Exp Cell Res $143: 247-255$

Thiebaud P, Icfresne J, Signoret J, David JC (1983) Isolation of the messenger RNA for 8S DNA ligase in early developing axolotl cgg and its cell free translation. Nucl Acids Res $11: 2563-2573$

Tomkins GM, Gelhrter ID, Granner D, Martin D, Samuels HH, Thomson EB (1969) Control of specific gene expression in higher organisms. Science 166:1474-1480

Tomkins GM, Levison BB, Baxter JD, Dethlefson L (1972) Further evidence for post transcriptional control of inducible tyrosine amino transferase synthesis in cultured hepatoma cells. Nature $239: 9-14$

Received March 29, 1985

Accepted in revised form September 20, 1985 